\title{
Pathophysiological Approach to Acid Base Disorders
}

\author{
Absar Ali \\ Aga Khan University \\ Karachi \\ Pakistan
}

\section{Introduction}

In this chapter, we are presenting the review of the acid base disorders. The emphasis is on the pathophysiology and the underlying concepts.

The complicated formulas and graphs are avoided and things are explained in the simple language. The basic acid base disorders namely metabolic acidosis, metabolic alkalosis, respiratory acidosis and respiratory alkalosis are discussed in detail. When appropriate the information is presented in the table forms to make it clear. Important references are also given for the interested readers.

\section{Basic concepts}

\subsection{Acid and base}

According to the standard definitions, acid is a substance which can donate $\mathrm{H}^{+}$ion and base is a substance which can accept $\mathrm{H}^{+}$ion (Ali, 1994; Boron, 2006; Kellum, 2007).

Acids are of two types.

1. Volatile acids for example carbon dioxide $\left(\mathrm{CO}_{2}\right)$ which is regulated by the alveolar ventilation in the lungs.

2. Non-volatile acids for example lactic acid, sulfuric acid, phosphoric acid, uric acid and, keto acid. These acids may not be converted to $\mathrm{CO}_{2}$ and hence must be removed from the body by the kidneys to keep the acid base in balance.

Acids and bases are also categorized according to their chemical behavior in the blood. They are called strong and weak. The strong acids and bases are completely ionized at the $\mathrm{pH}$ of 7.4. The weak acids and bases are ionized only partially at the $\mathrm{pH}$ of 7.4, depending upon their dissociation constant $(\mathrm{pKa})$. Hydrochloric Acid $(\mathrm{HCl})$ is a strong acid and Sodium Hydroxide $(\mathrm{NaOH})$ is a strong base. Sodium Bicarbonate $\left(\mathrm{Na} \mathrm{HCO}_{3}\right)$ is a weak acid (Boron, 2006; DuBose \& Hamm, 1999; Kellum, 2007).

\subsubsection{Acidemia}

Acidemia is defined as an increase in $\mathrm{H}^{+}$concentration of the blood. Acidemia may also be defined as a decrease in arterial $\mathrm{pH}$. 


\subsubsection{Alkalemia}

Alkalemia is defined as a decrease in the $\mathrm{H}^{+}$concentration of the blood. Alkalemia may also be defined as an increase in arterial $\mathrm{pH}$.

\subsection{Normal concentrations}

The normal concentration of $\mathrm{H}^{+}$in plasma or serum is $40 \mathrm{nmol} /$ liter and it varies inversely with the $\mathrm{HCO}_{3}{ }_{3}$ concentration.

The $\mathrm{pH}$ (Plasma concentration of $\mathrm{H}^{+}$) is the negative log of $\mathrm{H}$ concentration. Thus,

$$
\mathrm{pH}=-\log \left(\mathrm{H}^{+}\right) .
$$

The normal arterial $\mathrm{pH}$ is 7.40 , normal partial pressure of carbon dioxide $\left(\mathrm{PCO}_{2}\right)$ is 40 $\mathrm{mmHg}$. Normal serum bicarbonate $\left(\mathrm{HCO}_{-3}^{-3}\right)$ concentration is $24 \mathrm{mEq} / \mathrm{L}$.

Concentration of ions in a solution should be written in brackets. For example, for hydrogen ions as $\left(\mathrm{H}^{+}\right)$. However for the convenience it is often written with out brackets.

When coagulation factors are removed from the plasma, it is called serum. For practical purposes, plasma and serum are the same as far as the clinical medicine is concerned (DuBose \& Hamm, 1999).

\subsection{Buffers}

Buffers are weak acids, i.e. they do not dissociate completely at the $\mathrm{pH}$ of 7.4. They accept or donate $\mathrm{H}^{+}$ions to prevent large changes in the free $\mathrm{H}^{+}$ion concentration.

The body buffers are divided into 3 groups:

(1) Extracellular (2) intracellular, and (3) bone

\subsubsection{Extracellular buffers}

Bicarbonate is the most important extracellular buffer due to its high concentration and also due to its ability to control the $\mathrm{PCO}_{2}$ by alveolar ventilation. This system plays a central role in the maintenance of acid-base balance. $\mathrm{HCO}_{3} 3$ is regulated by renal $\mathrm{H}^{+}$excretion and $\mathrm{PCO}_{2}$ by the ventilation of lungs. Clinically, the acid base status of a person is expressed in terms of the principal extracellular buffer, the bicarbonate $/ \mathrm{CO}_{2}$ system.

Relationship between acid and base is expressed by the following equation:

$$
\left(\mathrm{H}^{+}\right)=24 \times \mathrm{CO}_{2} \div\left(\mathrm{HCO}_{3}^{-}\right)
$$

Henderson-Hasselbalch equation is the modified form of the above simpler equation: Henderson-Hasselbalch equation:

$$
\mathrm{pH}=6.10+\log \left(\mathrm{HCO}_{3}^{-}\right) \div\left(0.03 \times \mathrm{PCO}_{2}\right)
$$

$\mathrm{pH}$ is $\left(-\log \mathrm{H}^{+}\right), 6.10$ is the $\mathrm{pKa}, 0.03$ is solubility constant for $\mathrm{CO}_{2}$ in the extracellular fluid, and $\mathrm{PCO}_{2}$ is the partial pressure of carbon dioxide in the extracellular fluid.

Other, less important buffers in the extracellular fluid are phosphates and the plasma proteins.

\subsubsection{Intracellular buffers}

The intracellular buffers are phosphates, hemoglobin ( $\mathrm{Hgb})$, and proteins. 


$$
\begin{array}{rll}
\mathrm{H}^{+}+\mathrm{HPO}^{-2} & <-> & \mathrm{H}_{2} \mathrm{PO} 4^{-} \\
\mathrm{H}^{+}+\mathrm{Hgb}^{-} & <-> & \mathrm{HHgb} \\
\mathrm{H}^{+}+\text {Protein }^{-} & <-> & \text {HProtein }
\end{array}
$$

\subsubsection{Bone}

It is an important buffer for acid and base loads with as much as 40 percent contribution in buffering (Halperin \& Goldstein, 2002; Kellum, 2005).

\section{Types of acid base disorers}

There are four types of acid base disorders. A patient may present with one (simple) or more than one (mixed) disorder.

Metabolic Acidosis

Metabolic Alkalosis

Respiratory Acidosis

Respiratory Alkalosis

\subsection{Acidosis}

Acidosis is a process which tends to raise the hydrogen ion $(\mathrm{H}+)$ concentration.

\subsubsection{Metabolic acidosis}

When the process of acidosis is primarily due to retention of non volatile acid or due to bicarbonate loss, it is called metabolic acidosis. The arterial $\mathrm{pH}$ is low as well as serum bicarbonate concentration (Kraut \& Madias, 2010).

\subsubsection{Respiratory acidosis}

When the process of acidosis is primarily due to $\mathrm{CO} 2$ retention, it is called respiratory acidosis. The arterial $\mathrm{pH}$ is low and $\mathrm{PCO}_{2}$ is high (Corey, 2005).

\subsection{Alkalosis}

Alkalosis is a process which tends to lower the hydrogen $\left(\mathrm{H}^{+}\right)$concentration.

\subsubsection{Metabolic alkalosis}

When the process of alkalosis is primarily due to loss of non volatile acid or due to retention of bicarbonate, it is called metabolic alkalosis. The arterial $\mathrm{pH}$ is high as well as serum bicarbonate concentration (Corey, 2005).

\subsubsection{Respiratory alkalosis}

When the process of alkalosis is primarily due to $\mathrm{CO}_{2}$ loss, it is called respiratory alkalosis. The arterial $\mathrm{pH}$ is high and $\mathrm{PCO}_{2}$ is low.

Acidosis and alkalosis are the processes. Acidemia and alkalemia are the end result of these processes. Acidosis induces acidemia and alkalosis induces alkalemia.

In the body, these processes of acidosis and alkalosis never stop and one should use the terms acidosis and alkalosis rather than acidemia and alkalemia. 


\subsection{Compensations}

The body responds to acid and base disorder by changes to bring the $\mathrm{pH}$ towards normal value. In respiratory disorders, bicarbonate (HCO3) changes to compensate. In metabolic disorders, partial pressure of carbon dioxide $\left(\mathrm{P} \mathrm{CO}_{2}\right)$ changes to compensate. It is worthy of note that compensation always occurs in the same direction as the primary disorder (Adrogue \& Madias, 1998; Corey, 2005).

\section{Acute and chronic}

Respiratory acidosis and respiratory alkalosis are divided into two groups, acute and chronic, on the basis of their compensation. There are no plasma buffers for respiratory acidosis or alkalosis. The role of intracellular buffers and bone buffers is minor. The renal compensation takes about 3 to 5 days to complete.

Hence the acute phase continues for 3 to 5 days. Once full renal compensation is in place, the respiratory acidosis and respiratory alkalosis are called chronic.

On the other hand, metabolic acidosis and metabolic alkalosis are not divided into acute and chronic groups. However, sometimes the terms acute metabolic acidosis or alkalosis, and chronic metabolic acidosis or alkalosis are used. They indicate the time period, and not the compensatory response. In the metabolic disorders, the plasma buffers act immediately and respiratory compensation occurs quickly with in minutes to hours, so the acute phase, if any, is very brief (Schrier, 2003).

\section{Diagnosis of acid base disorders}

Evaluation of any acid-base disorder requires measurement of arterial blood gases (ABGs) and serum bicarbonate $\left(\mathrm{HCO}_{3}^{-}\right)$concentration. The Henderson-Hasselbalch equation shows that the $\mathrm{pH}$ is determined by the ratio of $\mathrm{HCO}_{3}^{-}$concentration to $\mathrm{PCO}_{2}$.

In metabolic acidosis, the primary event is a drop in the serum $\mathrm{HCO}_{3}^{-}$and $\mathrm{P} \mathrm{CO}_{2}$ drops as a secondary response. In respiratory alkalosis, the primary event is a drop in $\mathrm{PCO}_{2}$ and bicarbonate drops as a secondary event. $\mathrm{PCO}_{2}$ and $\mathrm{HCO}_{3}^{-}$both will be low in metabolic acidosis as well as in respiratory alkalosis. The $\mathrm{pH}$ will be low in metabolic acidosis and high in respiratory alkalosis (Boron, 2006; Corey, 2005; DuBose \& Hamm, 1999; Kellum, 2007; Lowenstein, 1993).

Similarly, $\mathrm{PCO}_{2}$ and $\mathrm{HCO}_{3}^{-}$will be high in metabolic alkalosis as well as in respiratory acidosis. The $\mathrm{pH}$ will be high in metabolic alkalosis and low in respiratory acidosis.

\begin{tabular}{|l|c|c|c|}
\hline Disorder & Primary Event & Secondary Event & pH \\
\hline Metabolic Acidosis & $\mathrm{HCO}_{3}^{-}$Low & $\mathrm{PCO}_{2}$ Low & Low \\
\hline Metabolic Alkalosis & $\mathrm{HCO}_{3}$ High & $\mathrm{PCO}_{2} \mathrm{High}$ & High \\
\hline Respiratory Acidosis & $\mathrm{PCO}_{2}$ High & $\mathrm{HCO}_{3} \mathrm{High}$ & Low \\
\hline Respiratory Alkalosis & $\mathrm{PCO}_{2}$ Low & $\mathrm{HCO}_{3}^{-}$Low & High \\
\hline
\end{tabular}

Table 1. Compensation in Simple Acid Base Disorders (Direction of primary and secondary event is always same)

The second step in the diagnosis of acid base disorders is to evaluate the degree of compensation. Once the disorder is diagnosed, the degree of compensation should be assessed. The expected degree of compensation is predefined on the basis of studies and experiments done by the scientists (Table 2). 


\begin{tabular}{|c|c|c|c|}
\hline Type of Disorder & $\begin{array}{l}\text { Primary } \\
\text { Change }\end{array}$ & Compensation Response & Expected pH \\
\hline $\begin{array}{l}\text { Metabolic } \\
\text { Acidosis }\end{array}$ & $\begin{array}{l}\text { Low } \\
\mathrm{HCO}_{3}^{-3}\end{array}$ & $\begin{array}{c}1.2 \mathrm{~mm} \mathrm{Hg} \text { drop in } \mathrm{PCO}_{2} \text { for every } 1 \\
\mathrm{mEq} / \mathrm{L} \text { drop in } \mathrm{HCO}_{3}(1.2: 1) \\
\mathrm{OR} \\
\mathrm{PCO}_{2}=1.5 \mathrm{HCO}_{3}+8+.2\end{array}$ & Last 2 digits of $\mathrm{PCO}_{2}$ \\
\hline $\begin{array}{l}\text { Metabolic } \\
\text { Alkalosis }\end{array}$ & $\begin{array}{l}\text { High } \\
\mathrm{HCO}^{-}\end{array}$ & $\begin{array}{c}0.7 \mathrm{~mm} \mathrm{Hg} \text { rise in } \mathrm{PCO}_{2} \text { for every } 1 \\
\mathrm{mEq} / \mathrm{L} \text { rise in } \mathrm{HCO}_{-}^{-}(0.7: 1)\end{array}$ & $\begin{array}{c}\text { From Henderson- } \\
\text { Hasselbalch equation }\end{array}$ \\
\hline $\begin{array}{l}\text { Acute Respiratory } \\
\text { Acidosis }\end{array}$ & High $\mathrm{PCO}_{2}$ & $\begin{array}{c}1 \mathrm{mEq} / \mathrm{L} \text { rise in } \mathrm{HCO}_{3} \text { for every } 10 \\
\mathrm{~mm} \mathrm{Hg} \text { rise in } \mathrm{PCO}_{2}(1: 10)\end{array}$ & $\begin{array}{l}0.08 \text { drop in } \mathrm{pH} \text { for } \\
\text { every } 10 \mathrm{~mm} \mathrm{Hg} \text { rise } \\
\text { in } \mathrm{PCO}_{2}\end{array}$ \\
\hline $\begin{array}{l}\text { Chronic } \\
\text { Respiratory } \\
\text { Acidosis } \\
\end{array}$ & High $\mathrm{PCO}_{2}$ & $\begin{array}{c}3.5 \mathrm{mEq} / \mathrm{L} \text { rise in } \mathrm{HCO}_{3} \text { for every } \\
10 \mathrm{~mm} \mathrm{Hg} \text { rise in } \mathrm{PCO}_{2} \text { (3.5:10) }\end{array}$ & $\begin{array}{l}0.03 \text { drop in } \mathrm{pH} \text { for } \\
\text { every } 10 \mathrm{~mm} \mathrm{Hg} \text { rise } \\
\text { in } \mathrm{PCO}_{2}\end{array}$ \\
\hline $\begin{array}{l}\text { Acute Respiratory } \\
\text { Alkalosis }\end{array}$ & Low $\mathrm{PCO}_{2}$ & $\begin{array}{l}2 \mathrm{mEq} / \mathrm{L} \text { drop in } \mathrm{HCO}_{3} \text { for every } \\
10 \mathrm{~mm} \mathrm{Hg} \text { drop in } \mathrm{PCO}_{2}(2: 10)\end{array}$ & $\begin{array}{l}0.08 \text { rise in } \mathrm{pH} \text { for } \\
\text { every } 10 \mathrm{~mm} \mathrm{Hg} \text { drop } \\
\text { in } \mathrm{PCO}_{2}\end{array}$ \\
\hline $\begin{array}{l}\text { Chronic } \\
\text { Respiratory } \\
\text { Alkalosis }\end{array}$ & Low $\mathrm{PCO}_{2}$ & $\begin{array}{l}4 \mathrm{mEq} / \mathrm{L} \text { drop in } \mathrm{HCO}_{3} \text { for every } \\
\text { 10-mm Hg drop in } \mathrm{PCO}_{2}(4: 10)\end{array}$ & $\begin{array}{c}0.03 \text { rise in } \mathrm{pH} \text { for } \\
\text { every } 10 \mathrm{~mm} \mathrm{Hg} \text { drop } \\
\text { in } \mathrm{PCO}_{2}\end{array}$ \\
\hline
\end{tabular}

Table 2. Expected Degree of Compensatory Responses

\subsection{Metabolic acidosis}

The diagnosis of a simple metabolic acidosis requires low serum bicarbonate and a low extracellular $\mathrm{pH}$.

\subsubsection{Mechanism of acid production}

The pathophsiology is better understood if we classify the metabolic acidosis on the basis of the mechanisms of acid production (Table 3).

\section{(1) Increased Acid (H+) Generation}

In these disorders, there is either an increased $\mathrm{H}^{+}$generation due to deranged metabolism in the body or by the increased administration of chemicals which are the source of $\mathrm{H}^{+}$ions. Examples of the first are lactic acidosis, keto acidosis and examples of the later are methanol poisoning, ethylene glycol poisoning, and salicylate poisoning.

\section{(2) Increased Loss of HCO-3}

In these disorders, the primary event is loss of $\mathrm{HCO}_{3}^{-3}$, which in turn leaves behind $\mathrm{H}^{+}$ions. Examples are diarrhea, ureteral diversion, and proximal renal tubular acidosis (RTA type 2).

\section{(3) Diminished Renal Acid (H+) Excretion}

In these disorders, there is decreased excretion of acid $\left(\mathrm{H}^{+}\right)$from the kidneys. The kidneys are responsible for removing the daily non volatile acid load and to increase the $\mathrm{H}^{+}$excretion in case of metabolic acidosis. Obviously, when kidneys themselves are not competent, metabolic acidosis will occur. Examples of decreased acid $\left(\mathrm{H}^{+}\right)$excretion are renal failure, distal renal tubular acidosis (RTA type 1), and RTA type 4 . 


\begin{tabular}{|c|}
\hline Increased Acid ( $\left.\mathrm{H}^{+}\right)$Generation \\
\hline $\begin{array}{l}\text { Lactic acidosis } \\
\text { Ketoacidosis } \\
\text { Methanol Poisoning } \\
\text { Ehylene Glycol Poisoning } \\
\text { Salicylate Poisoning }\end{array}$ \\
\hline Increased Loss Of $\mathrm{HCO}_{3}^{-}$ \\
\hline $\begin{array}{l}\text { Diarrhea } \\
\text { Ureteral diversion } \\
\text { Proximal renal tubular acidosis(Type 2) }\end{array}$ \\
\hline Diminished Renal Acid (H+) Excretion \\
\hline $\begin{array}{l}\text { Renal failure } \\
\text { Distal renal tubular acidosis (type } 1 \text { ) } \\
\text { Renal tubular acidosis type } 4\end{array}$ \\
\hline
\end{tabular}

Table 3. Important Causes of Metabolic Acidosis (According to the Mechanism )

\subsubsection{High and normal anion gap}

Metabolic Acidosis may also be divided in two groups according to the serum anion gap.

1. High Serum Anion Gap Metabolic Acidosis

2. Normal Serum Anion Gap Metabolic Acidosis (Table 4)

The terms gap and non gap metabolic acidosis are used sometimes. There is always an anion gap, normal, high, low, or negative. The gap/no gap terminologies should be abandoned.

\begin{tabular}{|l|}
\hline Increased Anion Gap \\
\hline Advaned Renal Failure \\
Lactic acidosis \\
Ketoacidosis \\
Methanol Poisoning \\
Ehylene Glycol Poisoning \\
Salicylate Poisoning \\
\\
\hline Normal Anion Gap \\
\hline Early Stages of Renal Failure \\
Renal Tubular Acidosis (all types) \\
Diarrhea \\
Ureteral diversion \\
\hline
\end{tabular}

Table 4. Important Causes of Metabolic Acidosis (According to the Serum Anion Gap) 
Serum Anion Gap (Serum AG) is the difference between the routinely measured cations i.e. sodium $(\mathrm{Na})$ and sum of routinely measured anions i.e. chloride

(Cl) and bicarbonate $\left(\mathrm{HCO}_{3}^{-}\right)$. It can be calculated from the following formula:

Serum AG = Routinely Measured Cations - Routinely Measured Anions

$$
\text { Serum } \mathrm{AG}=\mathrm{Na}-\left(\mathrm{Cl}+\mathrm{HCO}^{-} 3\right)
$$

Although, serum potassium $(\mathrm{K})$ is also routinely measured but it is omitted from calculations. The reasons for omission of $\mathrm{K}$ from calculation are twofold. First, its serum concentration range is small, and second, if it is changed drastically, patient will succumb to its consequences before the change in the anion gap is considered.

The serum anion gap may also be written as following.

Serum AG = Unmeasured anions - Unmeasured cations

Unmeasured anions are albumin, lactate, sulfate, urate, phosphate, and other anions. Unmeasured cations are potassium, magnesium, calcium, and other cations. Serum AG will increase when there is a rise in the unmeasured anions or fall in the unmeasured cations.

The serum anion gap (AG) will not increase if the $\mathrm{H}^{+}$ion is accompanied by chloride. Serum AG will increase if acid $\mathrm{H}^{+}$accompanies an anion other than chloride.

The normal range of the serum AG is $10 \pm 3 \mathrm{meq} / \mathrm{L}$. Negatively charged serum albumin contributes most of the serum AG. One $\mathrm{g} / \mathrm{dL}$ of serum albumin is equal to $2.5 \mathrm{meq} / \mathrm{L}$ of anion gap.

Examples of normal AG metabolic acidosis are diarrhea and RTA.

Examples of high AG metabolic acidosis are lactic acidosis, keto acidosis, renal failure, methanol poisoning, and ethylene glycol poisoning (Corey, 2005; Emmett \& Narins, 1997; Fidkowski \& Helstrom, 2009).

\subsubsection{Delta anion gap/delta bicarbonate}

The ratio of increase in serum Anion Gap to decrease in plasma bicarbonate is called Delta $\mathrm{AG}(\Delta \mathrm{AG}) /$ Delta $\left.\mathrm{HCO}_{3}{ }_{3}\left(\Delta \mathrm{HCO}_{3}\right)\right)$ ratio, or just $\Delta / \Delta$ ratio. It is a useful tool in sorting out the cause of metabolic acidosis.

In case of high anion gap metabolic acidosis, the drop in $\mathrm{HCO}_{3}$ should match the rise in the AG. In other words, the $\Delta / \Delta$ ratio should be 1:1. In lactic acidosis, AG increases more than the drop in serum $\mathrm{HCO}_{3}^{-3}$ and $\Delta / \Delta$ ratio may be as high as 1.6:1.

The reason for this discrepancy is buffering of the part of the $\mathrm{H}^{+}$by the intracellular and bone buffers. The part of the $\mathrm{H}^{+}$which is taken care by the intracellular and bone buffers does not lower the serum $\mathrm{HCO}_{3}$ concentration. The accompanied anion (lactate) remains in the extracellular fluid and raises the AG.

In ketoacidosis, the $\Delta \mathrm{AG} / \triangle \mathrm{HCO}_{3}^{-3}$ ratio is usually 1:1 due to partial excretion of ketones from the kidneys which balance out the intracellular and bone buffering. In mixed high anion gap and normal anion gap metabolic acidosis, the $\Delta \mathrm{AG} \Delta \mathrm{HCO}_{3}$ ratio will be less than one (Fidkowski \& Helstrom, 2009; Kellum, 2007; Rastegar, 2007).

In mixed metabolic alkadosis and metabolic acidosis, the $\Delta \mathrm{AG} / \Delta \mathrm{HCO}_{3}$ ratio will be more than 2. It this case, the drop in $\mathrm{HCO}_{3}^{-}$is much less than the rise in $\mathrm{AG}$ due to concomitant metabolic alkalosis. 
In the following paragraphs urinary anion gap, urinary osmolar gap, and serum osmolar gap are explained. These are the commonly used investigations in solving the complicated acid base disorders.

\subsubsection{Urinary anion gap}

The urinary anion gap is the difference between major urinary cations (sodium and potassium) and major urinary anions (chloride). It is calculated as follows:

$$
\text { Urinary Anion Gap = }(\mathrm{Na}+\mathrm{K})-(\mathrm{Cl})
$$

Urinary AG is an indirect measurement of urinary ammonium $\left(\mathrm{NH}^{+}{ }_{4}\right)$ excretion. Negative value means chloride concentration of urine is higher than the sum of sodium and potassium. Negative urine AG is an appropriate response to metabolic acidosis. An increased $\mathrm{NH}^{+}{ }_{4}$ excretion results in enhanced acid removal from the kidney, for example, in diarrhea (DuBose TD Jr, et al. 1991; Oh \& Carrol, 2002; Rose et al., 2001; Schoolwerth, 1991). Positive value means chloride concentration of urine is less than the sum of sodium and potassium. Positive urine anion gap indicates decreased $\mathrm{NH}^{+}{ }_{4}$ excretion, and decreased acid removal from the kidney, for example in renal tubular acidosis (Batlle et al., 1988).

\subsubsection{Urinary osmolar gap}

Just like urinary AG the urine osmolar gap (UAG) is a measure of urinary $\mathrm{NH}^{+}{ }_{4}$ excretion. An advantage of urine osmolar gap is that, it is not dependent on urinary chloride. It takes account of all the urinary anions accompanied with ammonium. It is calculated as follows:

Urinary Osmolar Gap = Measured urine osmolality - Calculated urine osmolality

Calculated urine osmolality $=$

$2 \times(\mathrm{Na}+\mathrm{K})+\underline{\text { Urine Urea Nitrogen }}+\underline{\text { Urine Glucose }}$

18

In the above formula, 2 indicates the anions accompanying sodium and potassium. $\mathrm{Na}$ and $\mathrm{K}$ are in meq/L , Urea Nitrogen and glucose are in $\mathrm{mg} / \mathrm{dl}$. (Kamel et al., 1990).

\subsubsection{Serum osmolar gap}

It is the difference between measured serum osmolality and calculated serum osmolality. Measured serum osmolality includes all the serum osmoles. Calculted osmolality includes only some selected ones (Kamel et al., 1990).

Calculated Serum Osmolality=

$$
2 \times \mathrm{Na}+\underline{\text { Blood Urea Nitrogen } \mathrm{mg} / \mathrm{dl}}+\underline{\text { Blood Glucose } \mathrm{mg} / \mathrm{dl}}
$$

In the above formulas, 2 indicates the anions accompanying sodium.

Normal serum osmolar gap is about 5 to 10. Examlpes of high osmolar gap metabolic acidosis are methanol and ethlylene glycol intoxication. There are conditions when serum osmolar gap is high with out acidosis, eg. mannitol infusion and ethanol ingestion (Lynd et al., 2008). 


\section{Stewart approach}

Traditionally, the hydrogen ion concentration $(\mathrm{pH})$ of blood is expressed as a function of the ratio of $\mathrm{PCO}_{2}$ and serum $\mathrm{HCO}_{3}^{-}$based upon Henderson-Hasselbalch equation.

An alternative approach was proposed by Stewart, which is called Stewart's approach or strong ion difference (SID) approach.

The SID is the difference between the concentration of strong cations and concentration of strong anions in the plasma. Major strong cations are $\mathrm{Na}^{+}, \mathrm{K}^{+}, \mathrm{Ca}^{++}, \mathrm{Mg}^{++}$, and the major strong anions are $\mathrm{Cl}^{-}$and lactate-

According to SID approach, there are six primary acid-base disturbances. These are respiratory acidosis, respiratory alkalosis, strong ion acidosis, strong ion alkalosis, nonvolatile buffer ion acidosis, and nonvolatile buffer ion alkalosis.

Stewart proposed that the serum bicarbonate concentration is not independent and does not play an active role in the determination of the $\mathrm{H}^{+}$concentration. According to Stewart's theory of SID, the plasma concentrations of nonvolatile weak acids and PCO2 are independent variables. Nonvolatile total weak acids are phosphate and charges of albumin. The $\mathrm{pH}$ depends upon these three variables and not on $\mathrm{HCO} 3 / \mathrm{PCO}_{2}$ ratio.

The SID method was presented by Stewart as an alternative to serum AG method for solving the acid-base problems. However, it did not get the popularity. Many physiologists believe that Stewart's method does not give any additional information if serum AG is corrected for serum albumin concentration (Fidkowski \& Helstrom, 2009; Kellum et al., 1995).

\section{Modified base excess method}

Base excess is the amount of acid or base that must be added to the solution to bring the $\mathrm{pH}$ to 7.4 at $\mathrm{PCO}_{2}$ of $40 \mathrm{mmHg}$ and temperature of $37^{\circ} \mathrm{C}$. Negative base excess means there is acidemia and positive base excess means there is alkalemia. The modified or sometimes called "standardized base excess method" is based upon Stewart's theory. It may be defined as the amount of strong acid or strong base required to bring the $\mathrm{pH}$ to 7.4 and $\mathrm{PCO}_{2}$ to 40 mmHg (Fidkowski \& Helstrom, 2009; Kraut \& Madias, 2007; Rastegar, 2009).

Arterial Blood Gas machine gives a calculated base excess value. Any therapeutic decision can not be taken on this calculated value because of two reasons. First, it may give a false value of zero when metabolic acidosis and metabolic alkalosis coexist. Second, it is impossible to predict the PCO2 level and $\mathrm{pH}$ after correcting the base excess or deficit.

This standardized base excess method does not give any advantage over traditional Henderson-Hasselbalch equation based methods.

In the following paragraphs important causes of metabolic acidosis are discussed.

\section{Chronic and acute renal failure}

The new name for chronic renal failure is chronic kidney disease and the new name for acute renal failure is acute kidney injury. Metabolic acidosis in renal failure results from reduced number of functioning nephrons. The single nephron function is intact.

The initial stages of renal dysfunction give rise to normal anion gap and later stages give rise to high anion gap metabolic acidosis. The anions accompanying the acid are sulfate, phosphate and urates. In early stages of renal failure, these anions are excreted without problem; thus the anion gap remains normal. 
In latter stages of renal failure, there is retention of these unmeasured anions and high anion gap metabolic acidosis develops (Kraut \& Kurtz, 2005; Narins \& Emmett, 1980).

\section{Methanol and ethylene glycol intoxication}

Methanol and ethylene glycol are ingested for pleasure as a substitute for ethanol, and also in the suicidal attempts, or taken accidently. Moonshine is a nick name of methanol when it is made illegally or locally using the radiators of the motor vehicles. Antifreeze solution contains high concentration of ethylene glycol (Lynd et al., 2008).

\subsection{Methanol}

Methanol is oxidized to formate by alcohol dehydrogenase and aldehyde dehydrogenase. Formate causes retinal injury with optic disc edema, blindness which may be permanent and basal ganglia injury.

High anion gap metabolic acidosis develops, due to accumulation of formate (formic acid). Serum AG is increased. (Kraut \& Kurtz, 2008). Serum osmolar gap is increased.

\subsection{Ethylene Glycol}

Ethylene Glycol is metabolized to glycolate (glycolic acid), oxalate (oxalic acid), and glyoxylate by alcohol dehydrogenase and aldehyde dehydrogenase. Renal failure occurs due to renal tabular damage by glycolic acid and precipitation of oxalate crystals in the kidneys. High anion gap metabolic acidosis develops due to accumulation of glycolic acid and oxalic acid . Serum AG is increased. (Kraut \& Kurtz, 2008). Serum osmolar gap is increased.

\section{Lactic acidosis}

Lactic acidosis is one of the most common causes of metabolic acidosis. Lactic acid is derived from the metabolism of pyruvic acid, which is generated from glucose and amino acids. Increased anaerobic metabolism lead to increased lactate production. The lactate produced in lactic acidosis is L-Lactate type, the accumulation of which gives rise to high anion gap.

The causes of lactic acidosis can be divided into type A, and type B. Type A lactic acidosis is associated with obviously impaired tissue oxygenation, for example, in shock, sepsis, hypovolemia, and cardiac failure.

In type B lactic acidosis, the impairment in oxygenation is not apparent. There is mitochondrial dysfunction due to toxins and drugs like metformin and nucleoside reverse transcriptase inhibitors (NRTIs).

\subsection{D-lactic acidosis}

D-lactate is produced in the colon from metabolism of starch and glucose by the grampositive anaerobes. In the setting of short bowel syndrome and malignancy, over production of D-lactate with severe metabolic acidosis may occur. Diagnosis may be difficult because the usual assays used in laboratories detect only L-lactate.

\section{Ketoacidosis}

Ketoacids are derived from metabolism of fatty acids in the liver. Normal metabolism of fatty acids give rise to formation of triglycerides, $\mathrm{CO}_{2}$, water, and ketoacids. However in the absence of insulin, ketoacids are produced out of proportion and cause acidosis. 
Ketoacids are; (1) $\beta$-Hydroxy butyric acid, and (2) Acetoacetic acid. Acetone is often grouped with Ketoacids but it is not an acid.

Uncontrolled Diabetes Mellitus is the most common cause of Ketoacidosis. Starvation and excessive alcohol intake may also give rise to mild to moderate ketoacidosis. Diagnosis of Ketoacidosis requires documentation of Ketones in the blood or urine (Arieff \& Carroll, 1972).

\section{Dilutional metabolic acidosis}

It is due to a fall in the serum bicarbonate concentration secondary to extracellular volume expansion by non bicarbonate fluid. Massive amounts of normal saline infusion may produce dilutional acidosis. It is not a clinically significant entity and only of academic interest

\section{Salicylate poisoning}

Aspirin (acetyl salicylic acid) poisoning results in mixed respiratory alkalosis and metabolic acidosis. Metabolic acidosis is due to accumulation of salicylic acid as well as lactic acid and ketoacids. Liver plays an important role in the detoxification of salicylate. In case of overdose, this system of detoxification saturates and results in deposition of salicylates in the tissues including brain.

\section{Renal Tubular Acidosis (RTA)}

There are 3 types of RTA:

Distal RTA (type 1)

Proximal RTA (type 2)

Hyporenin hypoaldosteronism (RTA type 4)

There is a Type 3 RTA also which is a rare autosomal recessive disorder due to carbonic anhydrase II deficiency and has features of both distal and proximal RTA (Table 5).

\begin{tabular}{|c|c|c|c|}
\hline & $\begin{array}{c}\text { Type I } \\
\text { Distal RTA }\end{array}$ & $\begin{array}{c}\text { Type II } \\
\text { Proximal RTA }\end{array}$ & Type IV RTA \\
\hline Primary defect & Decreased distal acidification & $\begin{array}{c}\text { Decreased } \\
\text { proximal } \\
\mathrm{HCO}^{-} \\
\text {reabsorption }\end{array}$ & $\begin{array}{c}\text { Aldosterone } \\
\text { deficiency } \\
\text { Rennin deficiency }\end{array}$ \\
\hline Urine $\mathrm{pH}$ & $>5.3$ & Variable & Usually $<5.3$ \\
\hline $\begin{array}{l}\text { Plasma } \mathrm{HCO}_{3} \\
\text { meq/L }\end{array}$ & Usually $<10$ & Usually 15-20 & Usually > 15 \\
\hline $\begin{array}{l}\text { Fractional } \\
\text { excretion of } \mathrm{HCO}_{3}^{-3}\end{array}$ & $<3 \%$ & 15 to $20 \%$ & $<3 \%$ \\
\hline Other abnormalities & $\begin{array}{l}\text { Nephrocalcinosis, } \\
\text { nephrolithiasis }\end{array}$ & Osteomalacia & $\begin{array}{l}\text { Common in } \\
\text { diabetics }\end{array}$ \\
\hline Plasma Potassium & Usually low & Usually low & High \\
\hline
\end{tabular}

Table 5. Comparison of Renal Tubular Acidosis 


\subsection{Distal RTA (type 1)}

In distal RTA, the main problem is impaired secretion of acid $\left(\mathrm{H}^{+}\right)$from the intercalated cells of the collecting tubules. Collecting tubules has two types of cells (1) principal cells, which are responsible for sodium and potassium balance, and (2) intercalated cells which are responsible for $\left(\mathrm{H}^{+}\right)$secretion and maintenance of acid base balance.

As a result of decreased $\mathrm{H}^{+}$secretion, there is decreased ammonium $\left(\mathrm{NH}^{+}\right.$) and decreased titratable acid excretion. Titratable acid means the acid removed by phosphate buffer system of urine. Anion Gap is normal because of retention of chloride along with $\mathrm{H}^{+}$ions.

Nephrocalcinosis and nephrolithiasis are known complication of RTA type 1 . High urine $\mathrm{pH}$ facilitates calcium phosphate precipitation and stone formation in the renal tubules and urinary collecting system (Batlle et al., 2006; Karet, 2009; Rodríguez, 2002).

\subsection{Proximal RTA (type 2)}

In RTA type 2, the proximal bicarbonate $\left(\mathrm{HCO}_{3}\right)$ reabsorption threshold is reduced and this results in the loss of filtered $\mathrm{HCO}_{3}^{-}$. Once a new steady state is achieved with low serum $\mathrm{HCO}_{3}$ the loss of bicarbonates ceases. Urine $\mathrm{pH}$ is initially high due to bicarbnonaturia and later may drop to less than 5.3 in untreated persons.

\subsection{Type 4 RTA}

In type 4 RTA, the primary defect is decreased potassium $(\mathrm{K})$ secretion from the distal nephron, mainly collecting tubules due to aldosterone deficiency or resistance. The decreased $\mathrm{H}^{+}$secretion and subsequent metabolic acidosis is secondary to defective $\mathrm{K}$ secretion. Most common cause of Type 4 RTA is hyporenin hypoaldosteronism syndrome. A decreased K secretion results in hyperkalemia and its treatment improves metabolic acidosis (Rodríguez, 2002).

\section{Metabolic alkalosis}

There are two stages of metabolic alkalosis:

(1) Generation of alkalosis, and (2) Maintenance of alkalosis

The kidneys are very efficient in correcting the metabolic alkalosis by excreting out the extra bicarbonate. Only generation of alkalosis is not sufficient to produce alkalemia. There must be some other factors present to maintain the alkalosis. Hypovolemia and hypochloremia are the most important etiologies responsible for maintenance of alkalosis (Table 6 and 7) (Khanna \& Kurtzman, 2006).

\subsection{Urine chloride}

Measurement of urine chloride concentration is a key test used in solving the differential diagnosis of metabolic alkalosis. It differentiates between hypovolemic and euvolemic states. In metabolic alkalosis, urine chloride is more reliable indicator of volume status as compared to urine sodium. Urine sodium may be high in spite of hypovolemia in metabolic alkalosis. It is due to the obligatory loss of sodium along with bicarbonate spill over.

Based upon urine chloride concentration, the causes of metabolic alkalosis may be divided in two groups (Table 8).

\subsection{Saline responsiveness}

Metabolic alkalosis may also be classified according to the response to saline administration. Urine chloride will be low in saline responsive alkalosis. Urine chloride may be high or low in saline resistant alkalosis. 


\begin{tabular}{|l|}
\hline Renal Loss of Acid $\mathbf{( \mathbf { H } ^ { + } )}$ \\
Diuretics \\
Hypermineralcoricoidosis \\
Post Hypercapnia \\
\hline Gastriointestinal Loss of Acid $\mathbf{( H}^{+} \mathbf{~}$ \\
Vomiting \\
Nasogastric Suction \\
Chloride Loosing Diarrhea \\
\hline Addition of Bicarbonate \\
Administration of Sodium Bicarbonate \\
Blood transfusion \\
Milk Alkali Syndrome \\
\hline Trans cellular Shift \\
Hypokalemia \\
\hline Excessive Hypotonic Fluid Loss \\
Contraction Alkalosis \\
\hline
\end{tabular}

Table 6. Important Causes of Metabolic Alkalosis (According to the mechanism)

\begin{tabular}{|c|}
\hline $\begin{array}{c}\text { Factors Responsible for Maintenance of } \\
\text { Metabolic Alkalosis }\end{array}$ \\
\hline Volume Depletion \\
Effective Circulatory Volume Depletion \\
Chloride Depletion \\
Hyperaldosteronism \\
Hypokalemia \\
\hline
\end{tabular}

Table 7. Factors Responsible for Maintenance of Metabolic Alkalosis.

\begin{tabular}{|l|l|}
\hline \multicolumn{2}{|c|}{$\begin{array}{c}\text { Causes of Metabolic Alkalosis } \\
\text { (According to Urine Chloride Concentration) }\end{array}$} \\
\hline \multicolumn{1}{|c|}{ Urine Chloride Concentration } \\
\hline $\begin{array}{l}\text { Less Than } 20 \text { meq/L } \\
\text { Hypovolumia }\end{array}$ & More than 40 meq/L \\
Vomiting & Diuretics \\
Nasogastric Suction & Hyperaldosteronism \\
Posthypercapnia & Bicarbonate Administration \\
& Bartter's Syndrome \\
& Gitelman's Syndrome \\
\hline
\end{tabular}

Table 8. Causes of Metabolic Alkalosis

\subsection{Saline responsive}

In these conditions, correction of hypovolemia will result in increased delivery of chloride and sodium to the distal nephron which will result in increased sodium bicarbonate excretion. Examples: Vomiting, Nasogastric Suction, Diuretics, Posthypercapnia. 


\subsection{Saline resistant}

In these conditions, the specific treatment of underlying cause is required to correct the alkalosis. Edematous states may respond to saline but may develop pulmonary edema and worsening of peripheral edema.

Examples: Congestive heart failure, Cirrhosis, Mineralocorticoid excess, Hypokalemia and Renal Failure.

Pathophysiology of the important causes of metabolic alkalosis is discussed below.

\subsection{Gastrointestinal losses}

The secretion of bicarbonate from the pancreas depends upon stimuli by the acid coming from stomach to the duodenum. Vomiting or nasogastric tube drainage prevents the acid from reaching the duodenum resulting in the decreased secretion of bicarbonate. The hdrochloric acid $(\mathrm{HCl})$ loss and retention of bicarbonate results in metabolic alkalosis.

\subsection{Diuretics}

The loop diuretics are the common cause of metabolic alkalosis. They produce alkalosis by volume contraction, increased urinary $\mathrm{H}^{+}$loss and hypokalemia.

\subsection{Hyperaldosteronism}

Primary and secondary mineralocorticoid excess results in metabolic alkalosis. It is primarily due to increased acid secretion from the distal nephron.

\subsection{Post hypercapnic alkalosis}

Rapid lowering of the blood carbon dioxide $\left(\mathrm{CO}_{2}\right)$ in chronic $\mathrm{CO}_{2}$ retainers will cause post hypercapnic metabolic alkalosis. Chronic retention of $\mathrm{CO}_{2}$ stimulates renal $\mathrm{HCO} 3$ retention to compensate for respiratory acidosis. Once $\mathrm{CO}_{2}$ content of the blood is reduced quickly, for example, by ventilator, the compensated $\mathrm{HCO}_{3}$ component is unmasked resulting in metabolic alkalosis.

\subsection{Milk alkali syndrome}

Excessive intake of calcium salts, for example calcium carbonate, may result in metabolic alkalosis, especially in renal failure. Carbonate is converted to $\mathrm{HCO}_{3}$ in the body and calcium decreases $\mathrm{HCO}_{3}$ excretion from the kidneys. It is called milk alkali syndrome because of its association with milk intake which contains large amounts of calcium.

\subsection{Hypokalemia}

Decreased plasma potassium $\left(\mathrm{K}^{+}\right)$level causes shift of $\mathrm{K}^{+}$from intracellular to extra cellular fluid, in an attempt to correct hypokalemia. To keep the electrical neutrality, $\mathrm{H}^{+}$shifts from outside to the inside of the cells. This loss of $\mathrm{H}^{+}$from extracellular fluid results in metabolic alkalosis.

It is interesting to note that metabolic alkalosis itself perpetuates hypokalemia. In metabolic alkalosis of any cause, transcellular shift of $\mathrm{H}^{+}$and $\mathrm{K}^{+}$takes place. $\mathrm{H}^{+}$ions move out of the cells to correct alkalosis and $\mathrm{K}^{+}$moves inside the cells producing hypokalemia.

\subsection{Bicarbonate administration}

As mentioned above, in euvolemic persons with normal renal function, it is impossible to produce alkalosis due to rapid renal excretion of any administered $\mathrm{HCO}_{3}$. However, in 
hypovolemia or in renal failure, administration of bicarbonates results in metabolic alkalosis simply due to inability of the kidneys to excrete the extra bicarbonates.

\subsection{Multiple blood transfusions}

Massive blood transfusion occasionally results in metabolic alkalosis. Citrate which is used as an anticoagulant in blood is converted to bicarbonate in the liver resulting in metabolic alkalosis.

\subsection{Contraction alkalosis}

Loss of water around a fixed amount of $\mathrm{HCO}_{-3}$ results in increased concentration of $\mathrm{HCO}_{3}^{-}$ and metabolic alkalosis. The increased pure water loss and hypotonic fluid loss by loop diuretics, excessive sweating and congenital chloride diarrhea are examples of conditions associated with contraction alkalosis.

\subsection{Bartter's syndrome and Gitelman's syndrome}

These are the autosomal recessive disorders characterized by hypokalemia and metabolic alkalosis.

In Bartter's syndrome, there is a defect in the sodium chloride transport in the thick ascending limb of the loop of Henle at the site of action of loop diuretics. The characteristic abnormalities include hypokalemia, metabolic alkalosis and increased urinary calcium excretion.

In Gitelman's syndrome, there is a defect in the sodium chloride transport in the distal tubule which is the site of action of thiazide diuretics. The characteristic abnormalities include hypokalemia, metabolic alkalosis, decreased urinary calcium excretion, and hypomagnesaemia.

\section{Respiratory acidosis and alkalosis}

\subsection{Respiratory acidosis}

The primary event in respiratory acidosis is retention of $\mathrm{CO}_{2}$. Metabolism of carbohydrates and fats results in the production of $\mathrm{CO}_{2}$ which combines with $\mathrm{H} 2 \mathrm{O}$ to form $\mathrm{H}_{2} \mathrm{HCO}_{3}$. It then dissociate into acid $\left(\mathrm{H}^{+}\right)$and bicarbonate $\left(\mathrm{HCO}_{-}^{-}\right)$.

$$
\mathrm{CO}_{2} \times 0.03+\mathrm{H} 2 \mathrm{O}<->\mathrm{H}_{2} \mathrm{HCO}_{3}^{-}<->\mathrm{HCO}_{3}^{-}+\mathrm{H}^{+}
$$

Kidneys compensate to respiratory acidosis by increasing acid $\left(\mathrm{H}^{+}\right)$excretion.

Lungs through alveolar ventilation remove $\mathrm{CO}_{2}$. In the absence of ventilation, $\mathrm{CO}_{2}$ will accumulate in the body and will result in severe acidosis (rise of free $\mathrm{H}^{+}$ions and drop of $\mathrm{pH}$ ). This type of acidosis is called respiratory acidosis (Arieff \& Carroll, 1972).

According to the Henderson-Hasselbalch equation, $\mathrm{pH}$ depends upon the ratio of bicarbonate and $\mathrm{PCO}_{2}$.

$$
\begin{gathered}
\left(\mathrm{H}^{+}\right)=24 \times \frac{\mathrm{PCO}_{2}}{\mathrm{HCO}_{3}^{-}} \\
\mathrm{pH}=6.10+\log \frac{\mathrm{HCO}_{3}^{-}}{0.03 \mathrm{P} \mathrm{CO}_{2}}
\end{gathered}
$$


The partial pressure of $\mathrm{CO}_{2}\left(\mathrm{PCO}_{2}\right)$ in the arterial blood is in equilibrium with that in the alveolar air. Normal arterial PCO2 is approximately $40 \mathrm{mmHg}$. CO2 is not an acid. It increases the acidity of the solution through the formation of $\mathrm{H}_{2} \mathrm{CO}_{3}$. Increased $\mathrm{PCO}_{2}$ will increases the $\mathrm{H}_{2} \mathrm{CO} 3$ concentration. It then dissociates into the acid $\left(\mathrm{H}^{+}\right)$and bicarbonate $\left(\mathrm{HCO}_{3} 3\right)$.

In contrast to metabolic acidosis, bicarbonate $\left(\mathrm{HCO}_{-3}^{-}\right)$does not act as a buffer in respiratory acidosis. It is part of the problem, not part of the solution. Sodium bicarbonate administration in respiratory acidosis is not beneficial, rather may be harmful. Administration of bicarbonate will result in an initial transient rise in $\mathrm{pH}$ due to the left shift. Then, $\mathrm{H}_{2} \mathrm{CO}_{3}$ will immediately dissociate and the net result will be higher $\mathrm{PCO}_{2}$, higher $\mathrm{HCO}_{-3}^{-3}$, higher $\mathrm{H}^{+}$, and lower $\mathrm{pH}$.

Intracellular buffers mostly hemoglobin $(\mathrm{Hgb})$ bind free $\mathrm{H}^{+}$and form $\mathrm{H}^{+}-\mathrm{Hgb}$ which is carried to lungs by the blood circulation. In the lungs, $\mathrm{H}^{+}$is released form $\mathrm{Hgb}$ and combines with available $\mathrm{HCO}_{3} 3$ to form $\mathrm{CO}_{2}$, which is exhaled by lungs to the atmosphere.

Increasing ventilation is the only treatment of respiratory acidosis. Renal response to increased $\mathrm{H}^{+}$excretion takes about 3 to 5 days to complete. At this stage, the respiratory acidosis is termed chronic. The $\mathrm{PCO}_{2} / \mathrm{HCO}_{3} 3$ ratio improves to settle $\mathrm{pH}$ at a higher level than it was in acute phase. This renal compensation is always suboptimal. If the $\mathrm{pH}$ is 7.4 or above, it means that there is a concomitant component of metabolic alkalosis.

The degree of compensation and expected $\mathrm{pH}$ after compensation are predefined (Table 2).

\subsubsection{Causes of respiratory acidosis}

The cause of respiratory acidosis is only one, that is, decreased ventilation. Several conditions can lead to decreased ventilation and respiratory acidosis. Causes of decreased ventilation may be divided into three groups. Important ones are listed here:

Central: Norcotics, Sedatives, Anaesthesia,

Peripheral: Neuropathies, Muscle weakness, Myopathies

Pulmonary and Airway Pathology: Pneumnia, Pneumothorax,Sleep apnea, and Emphysema.

\subsection{Respiratory alkalosis}

The primary event in respiratory alkalosis is decreased $\mathrm{PCO}_{2}$. According to the HendersonHasselbalch equation, $\mathrm{pH}$ depends upon the ratio of bicarbonate and $\mathrm{PCO}_{2}$ as mentioned above. Lower the $\mathrm{PCO}_{2}$, the higher the $\mathrm{pH}$ and vice versa.

Extracellular buffers are not efficient in respiratory alkalosis. Intracellular buffers e.g. protein, phosphate and $\mathrm{Hgb}$ act to release intracellular $\mathrm{H}^{+}$in an attempt to correct the alkalosis. This response also is not very efficient. Renal response of decreasing $\mathrm{H}^{+}$secretion takes 3 to 5 days to complete. At this stage, it is called chronic respiratory alkalosis.

\subsubsection{Causes of respiratory alkalosis}

Like respiratory acidosis, the cause of respiratory alkalosis is only one, that is, increased ventilation. Important causes of increased ventilation are listed here:

Hypoxemia, Sepsis, Salicylate intoxication, Pregnancy, stroke, Liver Failure, Psychological Causes, Artificial by ventilator (Kaplan \& Frangos, 2005).

\section{Conclusion}

Primary acid base disorders are metabolic acidosis, metabolic alkalosis, respiratory acidosis, and respiratory alkalosis. In practice, patients often present with mixed and complex acid 
base problems. Understanding the underlying pathophysiology is the best way of reaching at the correct diagnosis. The various formulae are helpful but are not substitute to the clear concepts.

\section{References}

Arieff AI, \& Carroll HJ. (1972). Nonketotic hyperosmolar coma with hyperglycemia: clinical features, pathophysiology, renal function, acid-base balance, plasma-cerebrospinal fluid equilibria and the effects of therapy in 37 cases. Medicine (Baltimore), Vol. 51, No. 2, pp.73-94.

Adrogue HJ, \& Madias NE. (1998). Medical progress: Management of life threatening acid base disorders. N Eng J Med, Vol. 338, No. 1, pp. 26-34.

Absar Ali. Nephrology on Fingertips. Florida: PIP Printers, 1994.

Batlle DC, Hizon M, Cohen E, Gutterman C, \& Gupta R. (1988). The use of the urinary anion gap in the diagnosis of hyperchloremic metabolic acidosis. N Engl J Med, Vol. 318, No.10, pp. 594-9.

Batlle D, Moorthi KM, Schlueter W, \& Kurtzman N. (2006). Distal renal tubular acidosis and the potassium enigma. Semin Nephrol, Vol. 26, No. 6, pp. 471-8.

Boron WF. (2006). Acid base transport by the renal proximal tubule. J Am Soc Nephrol, Vol. 17, No. 9, pp. 2368-82.

Corey HE. (2005). Fundamental principles of acid-base physiology. Crit Care, Vol. 9, No. 2, pp. 184-92.

Corey HE. (2003). Stewart and beyond: New models of acid base balance. Kidney Int, Vol. 64, No. 3, pp. 777-87.

Fidkowski C, \& Helstrom J. (2009). Diagnosing metabolic acidosis in the critically ill: bridging the anion gap, Stewart, and base excess methods. Can J Anaesth, Vol. 56, No. 3, pp. 247-56.

DuBose T, Hamm L. Acid base and eclectrolyte disorders: A companion to Brenner and Rector,s The kidney. Philadelphia: WB Saunders; 1999

DeFronzo RA. (1980). Hyperkalemia and hyporeninemic hypoaldosteronism. Kidney Int, Vol. 17, No. 1, pp. 118-34.

DuBose TD Jr, Good DW, Hamm LL, \& Wall SM. (1991). Ammonium transport in the kidney: new physiological concepts and their clinical implications. I Am Soc Nephrol, Vol. 1, No. 11, pp.1193-203.

Emmett M, \& Narins RG. (1997). Clinical use of the anion gap. Medicine (Baltimore), Vol. 56, No. 1, pp. 38-54.

Halperin M and Goldstein M. Fluid electrolyte and acid base physiology: Aproblem based approach. $3^{\text {rd }}$ edition. Philadelphia,WB Saunders;2002

Kellum JA. (2007). Disorders of acid base balance. Crit Care Med, Vol. 35, No. 11, pp. 2630-6.

Kellum JA, Kramer DJ, \& Pinsky MR. (1995). Strong ion gap: a methodology for exploring unexplained anions. J Crit Care, Vol. 10, No. 2, pp. 51-5.

Khanna A, \& Kurtzman NA. (2006). Metabolic alkalosis. J Nephrol, Vol. 19, Suppl. 9, pp. S8696.

Kraut JA, \& Madias NE. (2010). Metabolic acidosis: pathophysiology, diagnosis and management. Nat Rev Nephrol, Vol. 6, No. 5, pp. 274-85.

Kellum JA. (2005). Clinical Review: Reunification of acid base physiology. Crit Care, Vol. 9, No. 5, pp. 500-7. 
Karet FE. (2009). Mechanisms in hyperkalemic renal tubular acidosis. J Am Soc Nephrol, Vol. 20, No. 2, pp.251-4.

Kamel KS, Ethier JH, Richardson RM, Bear RA, Halperin ML. (1990). Urine electrolytes and osmolality: when and how to use them. Am J Nephrol, Vol. 10, No. 2, pp. 89-102.

Kellum JA. (2005). Determinants of plasma acid-base balance. Crit Care Clin, Vol. 21, No. 2, pp. 329-46.

Kraut JA, Madias NE. (2007). Serum anion gap: Its uses and limitations in clinical medicine. Clin J Am Soc Nephrol, Vol. 2, No. 1, pp.162-74.

Kraut JA, \& Kurtz I. (2005). Metabolic acidosis of CKD: diagnosis, clinical characteristics, and treatment. Am J Kidney Dis, Vol. 45, No. 6, pp.978-93.

Kraut JA, \& Kurtz I. (2008). Toxic alcohol ingestions: clinical features, diagnosis, and management. Clin J Am Soc Nephrol, Vol. 3, No. 1, pp. 208-25.

Lowenstein. Acids and Basics. New York University, 1993

Kaplan LJ, \& Frangos S. (2005). Clinical review: Acid-base abnormalities in the intensive care unit. Crit Care, Vol. 9, No. 2, pp. 198-203.

Lynd LD, Richardson KJ, Purssell RA, Abu-Laban RB, Brubacher JR, Lepik KJ, \& Sivilotti ML. (2008). An evaluation of the osmole gap as a screening test for toxic alcohol poisoning. BMC Emerg Med, Vol. 8, No. 5.

Narins RG, \& Emmett M. (1980). Simple and mixed acid-base disorders: a practical approach. Medicine (Baltimore), Vol. 59, No. 3, pp.161-87.

Rose B, Narins R, Post T. Clinical Physiology of Acid base and Electrolyte Disorders. New York. McGraw Hill, Medical Publishing Division; 2001

Oh M, \& Carroll HJ. (2002). Value and determinants of urine anion gap. Nephron, Vol. 90, No. 3, pp. 252-5.

Rastegar A. (2007). Use of the DeltaAG/DeltaHCO3 ratio in the diagnosis of mixed acidbase disorders. J Am Soc Nephrol, Vol. 18, No. 9, pp. 2429-31.

Rastegar A. (2009). Clinical utility of Stewart's method in diagnosis and management of acid-base disorders. Clin J Am Soc Nephrol, Vol. 4, No. 7, pp.1267-74.

Rodríguez Soriano J. (2002). Renal tubular acidosis: the clinical entity. J Am Soc Nephrol, Vol. 13, No. 8, pp. 2160-70.

Rose B, \& Post TW. Clinical Physiology of Acid-Base and Electrolyte Disorders, 5th ed, McGraw-Hill, New York, 2001

Schrier R, Renal and Electrolyte Disorders. $6^{\text {th }}$ edition. Philadelphia: Lippincott Williams and Wilkins, 2003

Schoolwerth AC. (1991). Regulation of renal ammoniagenesis in metabolic acidosis. Kidney Int, Vol. 40, No. 5, pp. 961-73. 


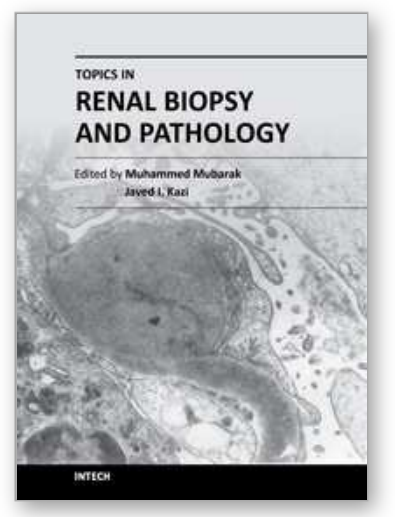

\author{
Topics in Renal Biopsy and Pathology \\ Edited by Dr. Muhammed Mubarak
}

ISBN 978-953-51-0477-3

Hard cover, 284 pages

Publisher InTech

Published online 04, April, 2012

Published in print edition April, 2012

There is no dearth of high-quality books on renal biopsy and pathology in the market. These are either single author or multi-author books, written by world authorities in their respective areas, mostly from the developed world. The vast scholarly potential of authors in the developing countries remains underutilized. Most of the books share the classical monotony of the topics or subjects covered in the book. The current book is a unique adventure in that it bears a truly international outlook and incorporates a variety of topics, which make the book a very interesting project. The authors of the present book hail not only from the developed world, but also many developing countries. The authors belong not only to US but also to Europe as well as to Pakistan and Japan. The scientific content of the book is equally varied, spanning the spectrum of technical issues of biopsy procurement, to pathological examination, to individual disease entities, renal graft pathology, pathophysiology of renal disorders, to practice guidelines.

\title{
How to reference
}

In order to correctly reference this scholarly work, feel free to copy and paste the following:

Absar Ali (2012). Pathophysiological Approach to Acid Base Disorders, Topics in Renal Biopsy and Pathology, Dr. Muhammed Mubarak (Ed.), ISBN: 978-953-51-0477-3, InTech, Available from:

http://www.intechopen.com/books/topics-in-renal-biopsy-and-pathology/pathophysiological-approach-to-acidbase-disorders

\section{INTECH}

open science | open minds

\author{
InTech Europe \\ University Campus STeP Ri \\ Slavka Krautzeka 83/A \\ 51000 Rijeka, Croatia \\ Phone: +385 (51) 770447 \\ Fax: +385 (51) 686166 \\ www.intechopen.com
}

\author{
InTech China \\ Unit 405, Office Block, Hotel Equatorial Shanghai \\ No.65, Yan An Road (West), Shanghai, 200040, China \\ 中国上海市延安西路65号上海国际贵都大饭店办公楼 405 单元 \\ Phone: +86-21-62489820 \\ Fax: +86-21-62489821
}


(C) 2012 The Author(s). Licensee IntechOpen. This is an open access article distributed under the terms of the Creative Commons Attribution 3.0 License, which permits unrestricted use, distribution, and reproduction in any medium, provided the original work is properly cited. 